\title{
PENERAPAN MAKE A MATCH TERHADAP HASIL BELAJAR KOGNITIF PADA PEMBELAJARAN IPA
}

\author{
Oleh \\ ${ }^{1}$ Amin Mustajab, ${ }^{2}$ Tri Syamsijulianto, ${ }^{3}$ Hamdiah Susanti \\ ${ }^{1}$ STKIP Melawi, ${ }^{2}$ STKIP Melawi, ${ }^{3}$ SDN 13 Pesing \\ aminmustajab53@gmail.com, syamsijulianto17@gmail.com, \\ hamdiah.susanti12@gmail.com
}

Diterima 7 Mei 2021 direvisi 15 Agustus 2021, diterbitkan 1 Oktober 2021

\begin{abstract}
Penelitian ini bertujuan untuk mengetahui mendeskripsikan proses pembelajaran IPA dan untuk melihat tingkat keberhasilan penerapan model Make a Match terhadap hasil belajar peserta didik di kelas VI semester II Sekolah Dasar Negeri 13 Pesing Kecamatan Sekayam tahun pelajaran 2019/2020. Subjek penelitian adalah peserta didik kelas VI dengan jumlah peserta didik 18 orang terdiri dari 4 peserta didik lakilaki dan 14 peserta didik perempuan.Penulis menerapkan keberhasilan model pembelajaran Make a Match terhadap hasil belajar kognitif pada pembelajaran IPAdi kelas VI sekolah Dasar Negeri 13 Pesing. Instrumen penelitian yang digunakan adalah lembar pre test dan post test dalam bentuk uraian dan non-tes (observasi). Metode penelitian yang digunakan adalah dengan menggunakan penelitian tindakan kelas (PTK). Berdasarkan pembahasan hasil penelitian dapat disimpulkan bahwa terdapat peningkatan dari siklus I pertemuan 1 ke siklus II sebesar $61 \%$ dengan kategori sangat baik. Pada siklus II terdapat $89 \%$ persentase tingkat keberhasilan pembelajaran peserta didik sudah berada pada kriteria sangat baik. Sedangkan rata-rata nilai pada siklus II sebesar 82, penelitian ini sudah memenuhi kriteria keberhasilan. Dari uraian hasil belajar kognitif tersebut, peneliti menyimpulkan bahwa pembelajaran dengan penerapan model Make a Match dapat meningkatkan hasil belajar kognitif peserta didik sehingga tujuan dari penelitian ini tercapai dengan hasil yang memuaskan.
\end{abstract}

\section{Kata Kunci: Model Make A Match, Hasil Belajar Kognitif, Pembelajaran IPA}

\begin{abstract}
The purpose of this research was to describe the science learning process and to observe the success rate of implementing Make a Match model on the learning outcomes of students in grade VI, second Semester Elementary School 13 Pesing,Sekayam district, academic year 2019/2020. The research subjects were 18
\end{abstract}


ADI WIDYA: Jurnal Pendidikan Dasar

FAKULTAS DHARMA ACARYA

UNIVERSITAS HINDU DARMA NEGERI

DENPASAR
Volume. 6, Nomor 2 Bulan Oktober 2021

ISSN: 2685-8312 (online)

ISSN: 2527-5445 (cetak)

http://ejournal.ihdn.ac.id/index.php/AW

students, 4 male and 14 female students. The researcher applied the successful of make a match model toward cognitive learning outcome in science learning of grade 6 Elementary school 13 Pesing. The research instrument used pre-test and post-test in the essay forms and non-tests (observations).The methode of research used is by using class action research (PTK). Based on the discussion of the research result, it can be concluded that there was an increase from the first cycle of first meeting to the second cycle of $61 \%$ with the very good category. In the second cycle there was $89 \%$ percentage of successful rate students' learning in very good criteria. While, the average score in second cycles was 82 , this research achieved the successful criteria. From the description of the students' cognitive learning outcome, the researcher concludes that learning with Make A Match model can increase students' cognitive outcome so that the objectives of this research has achieved satisfactory results.

\section{Keywords: Make A Match, Learning Outcomes, Science Learning.}

\section{PENDAHULUAN}

Pendidikan merupakan hal yang paling penting dalam kehidupan, baik secara individu, maupun dalam kehidupan berbangsa(Prihatiningsih \& Setyanigtyas, 2018). Pendidikan sangat penting untuk menciptakan masyarakat yang cerdas, disiplin, kritis, dan demokratis (Susanti, 2018). Namun terdapat masalah pada dunia pendidikan di Indonesia. Salah satu diantara masalah besar dalam bidang pendidikan di Indonesia yang banyak diperbincangkan adalah rendahnya mutu pendidikan yang tercermin dari rendahnya ratarata hasil belajar. Mutu pendidikan merupakan dua istilah yang berasal dari mutu dan pendidikan, artinya menunjuk pada kualitas produk yang di hasilkan lembaga pendidikan atau sekolah (Aziz, 2015).

Keberhasilan pendidikan harus ditunjang oleh kemampuan guru dalam mengajar. Dalam proses pengajaran seorang guru harus mengembangkan strategi mengajar yang mengarah keaktifan optimal belajar siswa (Rijal \& Bachtiar, 2015). Dengan demikian maka seorang guru tidak hanya dituntut untuk mampu menguasai materi pelajaran saja (Mustajab et al., 2020), akan tetapi juga dituntut untuk mampu mengembangkan metode-metode mengajar yang sesuai dengan tujuan pendidikan (Fiteriani \& Baharudin, 2017). Metode mengajar yang dimaksud agar siswa dapat dengan mudah memahami pelajaran yang diajarkan (Mikran et al., 2014). Dengan penerapan model pembelajaran yang kurang inovatif siswa juga kurang mengembangkan kemampuan yang mereka miliki terutama kemampuan kognitif (Melda et al., 2019).

Kesulitan siswa dalam belajar erat kaitannya dengan perkembangan kognitif siswa. Menurut teori kognitif, belajar menunjukkan adanya jiwa yang sangat aktif, jiwa mengolah informasi yang diterima, tidak sekedar menyimpannya saja tanpa mengadakan transformasi 
ADI WIDYA: Jurnal Pendidikan Dasar

FAKULTAS DHARMA ACARYA

UNIVERSITAS HINDU DARMA NEGERI

DENPASAR
Volume. 6, Nomor 2 Bulan Oktober 2021

ISSN: 2685-8312 (online)

ISSN: 2527-5445 (cetak)

http://ejournal.indn.ac.id/index.php/AW

(Prihatiningsih \& Setyanigtyas, 2018). Dalam menempuh proses pembelajaran, siswa tidak hanya sekedar bersifat pasif dalam menerima pengetahuan (Prihatiningsih \& Setyanigtyas, 2018). Ranah kognitif terdiri dari enam jenis perilaku yaitu pengetahuan, pemahaman, penerapan, analisis, sintesis dan evaluasi (Subekti \& Ariswan, 2016).

Temuan dari (Wiyoko \& Aprizan, 2020) profil kemampuan kognitif berupa kemampuan mengingat (C1) sebesar 75\%, kemampuan memahami (C2) sebesar 90\%, kemampuan mengaplikasikan sebesar $57,50 \%$ dan kemampuan menganalisis $30 \%$. Salah satu kemungkinan penyebab rendahnya kemampuan kognitif siswa karena pelaksanaan pembelajaran di sekolah masih menggunakan pembelajaran konvensional. Oleh karena itu pembelajaran harus lebih bersifat informatif yaitu guru menyampaikan materi kepada siswa secara utuh serta melibatkan siswa dalam proses pembelajaran (Kurniawan et al., 2017). Salah satu model pembelajaran yang dapat melibatkan siswa secara aktif selama proses pembelajaran adalah model pembelajaran make a match.

Metode make a match merupakan metode belajar mengajar mencari pasangan dimana siswa mencari pasangan sambil belajar mengenai suatu konsep atau topik dalam suasana yang menyenangkan (Sirait, Makmur, 2013). Jumlah siswa dalam satu kelompok tidak boleh terlalu besar, yang terdiri dari 2 orang atau lebih (Juliani et al., 2021). Model pembelajaran make a match bisa diterapkan untuk semua mata pelajaran dan tingkatan kelas karena memilki kelebihan yaitu siswa mencari pasangan sambil belajar tentang konsep atau topik dalam suasana yang menyenangkan (Kaharuddin, 2018). Metode ini sangat disenangi siswa lantaran tidak menjemukan karena guru memancing kreativitas siswa dengan menggunakan media (Wibowo \& Marzuki, 2015). Model make a match terbukti dapat meningkatkan aktivitas belajar siswa pada mata pelajaran Matematika yaitu materi mengubah pecahan ke bentuk persen (Tarigan, 2014).

Berdasarkan uraian, teori dan hasil penelitian relevan yang sudah dijelaskan maka pada penelitian kali ini, peneliti tertarik untuk menerapakan model pembelajaran make a match terhadap hasil belajar kognitif siswa.

\section{METODE}

Metode yang digunakan pada penelitian ini adalah metode penelitian tindakan kelas (Class Action Research). Penelitian ini melibatkan guru kelas VI selaku peneliti pelaksana dan beberapa kawan sejawat sebagai pengamat observasi. Subjek penelitian adalah peserta didik kelas VI Sekolah Dasar Negeri 13 Pesing Kecamatan Sekayam kabupaten sanggau kalimantan barat dengan jumlah peserta didik 18 orang terdiri dari 4 peserta didik laki-laki dan 14 peserta didik perempuan. Objek penelitian adalah penerapan model Make A Match yang digunakan untuk meningkatkan hasil belajar kognitif dalam pembelajaran IPA pada

peserta didik kelas VI Sekolah Dasar Negeri 13 Pesing. Desain PTK yang digunakan pada 
penelitian ini mengacu pada Kemmis dan Taggard (Basuki, 2003). Model ini terdiri dari siklus-siklus yang saling berhubungan dimana pada tiap-tiap siklus terdiri dari tahaptahapan perencanaan, tindakan, pengamatan (observasi), refleksi. Siklus I belum mencapai indikator yang ditargetkan maka dilanjutkan dengan sikus II yaitu perbaikan rencana, tindakan, pengamatan, dan refleksi. Siklus berikutnya selalu dimulai dengan perbaikan tindakan dari siklus sebelumnya (Yanti et al., 2020). Teknik analisis data menggunakan uji analis deskriptif sederhana.

\section{PEMBAHASAN}

Hasil tindakan penelitian pada setiap siklus ini yaitu pre test dan post test untuk mengukur hasil belajar kognitif peserta didik. Hasil tes masuk ke ranah kognitif yaitu menguji pengetahuan dan pemahaman peserta didik dengan mengerjakan soal pre test dan post tes berupa soal essay yang diberikan oleh peneliti kepada peserta didik pada awal dan akhir pertemuan. Peneliti mendapatkan nilai hasil belajar peserta didik dalam proses pembelajaran pada tiap siklus. Hasil belajar kognitif pre test dan post test pada tiap siklus dapat dilihat pada grafik berikut.

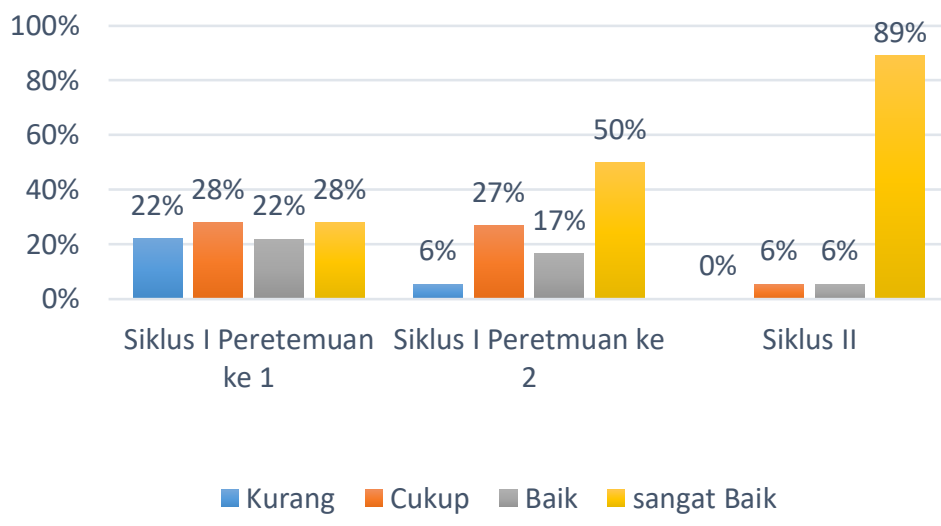

Sumber (Mustajab, Syamsijulianto, \& Susanti, 2021)

Gambar 1 Persentase tingkat keberhasilan Pembelajaran Menggunakan Model Make A Match pada Tiap Siklus 
ADI WIDYA: Jurnal Pendidikan Dasar

FAKULTAS DHARMA ACARYA

UNIVERSITAS HINDU DARMA NEGERI

DENPASAR
Volume. 6, Nomor 2 Bulan Oktober 2021

ISSN: 2685-8312 (online)

ISSN: 2527-5445 (cetak)

http://ejournal.ihdn.ac.id/index.php/AW

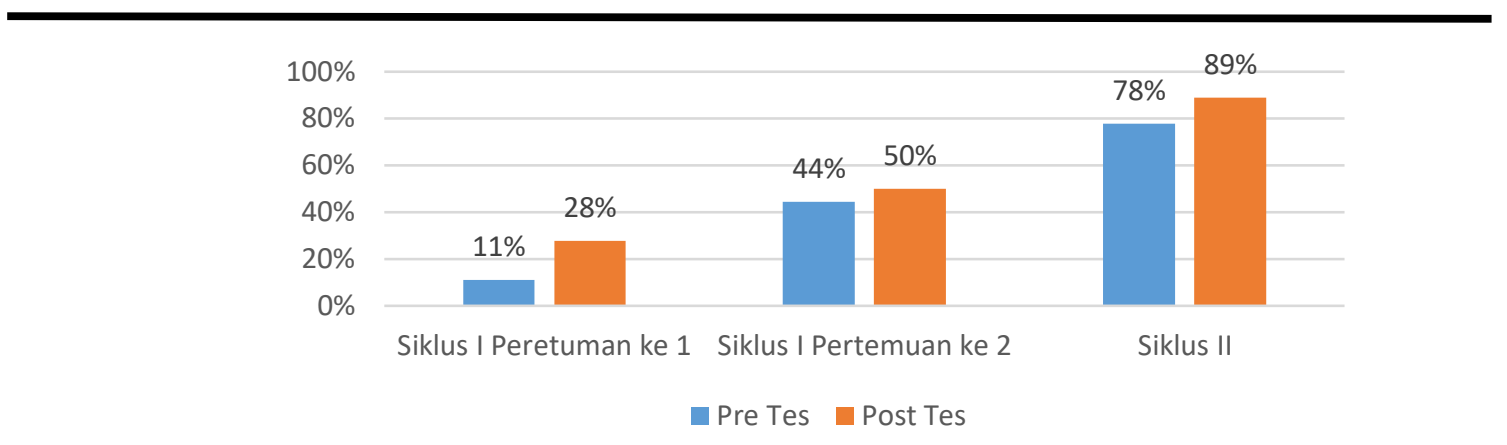

Sumber (Mustajab, Syamsijulianto, \& Susanti, 2021)

\section{Gambar 2 Persentase Tingkat Ketuntasan Pre tes dan Post tes Pada Tiap Siklus}

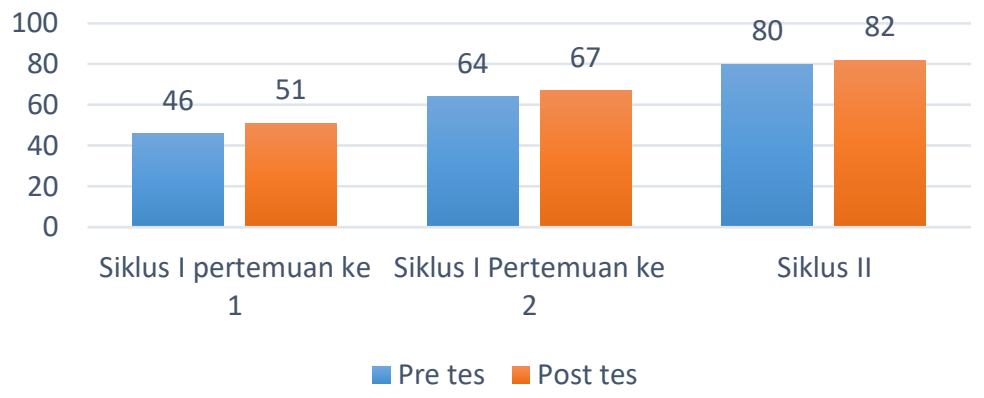

Sumber (Mustajab, Syamsijulianto, \& Susanti, 2021)

\section{Gambar 3 Rerata Nilai Pre tes dan Post tes Tiap Siklus}

Berdasarkan gambar 1. Persentase Kriteria Keberhasilan peserta didik pada siklus I pertemuan ke $122 \%$ berada pada kategori kurang, 28\% berada pada kategori cukup baik, $22 \%$ berada pada kategori baik dan $28 \%$ berada pada kategori sangat baik. Persentase kriteria keberhasilan peserta didik pada siklus I pertemuan ke 2 sebesar $6 \%$ berada pada kategori kurang, 27\% berada pada kategori cukup baik, 17\% berada pada kategori baik, dan $50 \%$ berada pada kategori sangat baik. Persentase kriteria keberhasilan peserta didik pada siklus II sebesar $0 \%$ berada pada kategori kurang, 60\% berada pada kategori cukup baik, $60 \%$ berada pada kategori baik, dan $88 \%$ berada pada kategori sangat baik.

Berdasarkan gambar 2. Persentase Tingkat Ketuntasan pada hasil belajar pre tes pada siklus I pertemuan ke 1 sebesar 11\% dengan jumlah peserta yang lulus sebanyak 2 orang dari jumlah peserta didik 18 orang. Sedangkan nilai post tes sebesar $28 \%$ dengan jumlah peserta didik yang lulus sebanyak 5 orang dari jumlah peserta didik 18 orang. Pada siklus I pertemuan ke 2 tingkat persentase kelulusan pre tes sebesar $44 \%$ dengan jumlah peserta yang lulus sebanyak 8 orang dari jumlah peserta didik 18 orang dan nilai post tes sebesar $50 \%$ dengan jumlah peserta didik yang lulus sebanyak 9 orang. Sedangkan pada siklus II tingkat persentase kelulusan pre tes sebesar $78 \%$ dengan jumlah peserta didik yang lulus 
ADI WIDYA: Jurnal Pendidikan Dasar

FAKULTAS DHARMA ACARYA

UNIVERSITAS HINDU DARMA NEGERI

DENPASAR
Volume. 6, Nomor 2 Bulan Oktober 2021

ISSN: 2685-8312 (online)

ISSN: 2527-5445 (cetak)

http://ejournal.indn.ac.id/index.php/AW

sebanyak 14 orang dan nilai post tes sebesar $89 \%$ dengan jumlah peserta didik yang lulus sebanyak 16 orang.

Berdasarkan gambar 3. Rata-rata hasil belajar kognitif pre tes siklus I pertemuan ke 1 sebesar 46, siklus I pertemuan ke 2 dengan rata-rata sebesar 64, siklus II dengan rata-rata sebesar 80 . Sedangan rata-rata hasil belajar kognitif post tes siklus I pertemuan ke I sebesar 51, siklus I pertemuan ke 2 dengan rata-rata sebesar 67 dan siklus II dengan rata-rata nilai sebesar 82. Berdasarkan gambar 2. Terjadi peningkatan ketuntasan hasil belajar post tes nya yaitu siklus I pertemuan ke 1 sebesar 28\%, siklus I pertemuan ke 2 sebesar $50 \%$ dan siklus II sebesar $89 \%$. Hal ini disebabkan karena pada langkah-langkah pembelajaran peneliti melakukan apersepsi dengan memotivasi peserta didik dengan mengaitkan materi yang telah di pelajari dengan materi yang akan disampaikan. Hal ini sejalan dengan temuan (Sirait, Makmur, 2013), berdasarkan penelitiannya dapat dilihat bahwa hasil belajar siswa yang diajarkan dengan model pembelajaran kooperatif tipe Make a Match lebih tinggi dari pada hasil belajar siswa yang diajarkan dengan model pembelajaran langsung, karena pada model pembelajaran kooperatif tipe Make a Match memberikan kesempatan kepada siswa untuk saling memberikan pendapat atau ide yang mereka miliki.

Keberhasilan peneliti di raih dengan meningkatkan kepercayaan diri dan telah mampu menguasai kelas saat pembelajaran berlangsung. Keberhasilan peserta didik dalam proses pembelajaran bergantung pada aktivitas di sekolah yang begitu komplek (Bahri \& Mustajab, 2020). Melalui pembelajaran yang menyenangkan dan sesuai dengan karakteristik peserta didik tentu akan memberikan dampak pembelajaran (Syamsijulianto, 2020b). Peserta didik dilibatkan dalam pembelajaran dalam penerapan model Make A Match yaitu mencocokkan kartu soal dan kartu jawaban (Mikran et al., 2014). Dimana sebelumnya peneliti sudah menjelaskan terlebih dahulu kepada peserta didik cara mencocokan kartu soal dan kartu jawaban dalam penerapan model Make a Match tersebut. Penggunaan kartu pada proses kegiatan pembelajaran memberikan pembelajaran yang bermakna dan menguatkan konsep belajar peserta didik (Syamsijulianto et al., 2020). Sehingga peseta didik merasa senang dan bersemangat, dapat memahami materi dengan baik, terbukti dengan peningkatan hasil belajar kognitif post tes yang telah di berikan. Dengan demikian terbukti terjadinya peningkatan proses pembelajaran IPA dengan model Make A Match di kelas VI Sekolah Dasar Negeri 13 Pesing

Pada pelaksanaan tindakan siklus II, peneliti telah memfokuskan pada kekurangan-kekurangan pada siklus I dengan cara memperbaiki strategi belajar yang dilakukan peneliti berhasil dengan kriteria baik meraih persentase ketuntasan nilai pre tes $78 \%$ sedangkan nilai post tes dengan kriteria sangat baik meraih ketuntasan sebesar $89 \%$. Dengan peningkatan persentase nilai pre tes $34 \%$ dan nilai post tes meningkat sebesar $39 \%$. Hasil belajar meningkat pada siklus II ini, diraih dengan upaya peneliti memberi pemahaman yang tepat dan baik dalam penerapan model Make A Match dengan mencocokkan kartu 
dengan mencari pasangan masing-masing kartu soal dan kartu jawaban betul-betul dapat di pahami dari masing-masing kartu yang diperoleh peserta didik. Peserta didik mampu memahami dan menyimpulkan makna dari kartu soal dan kartu jawaban dari penerapan model Make A Match yang mereka dapatkan. Penyampaian materi yang di jelaskan oleh peneliti dengan penerapan model Make A match atau mencocokan dengan mencari pasangan membuat peserta didik mudah memahami materi dan pemanfaatan waktu menjadi lebih optimal. Peningkatan hasil belajar pada setiap tindakan yang dilakukan menjadi bukti bahwa dengan penerapan model Make a Match dapat meningkatkan hasil belajar peserta didik. Peningkatan hasil belajar siswa dapat disebabkan oleh proses belajar yang dilaksanakan mampu untuk meningkatkan sikap dan keterampilan peserta didik (Syamsijulianto, 2020a). Hal ini sejalan dengan temuan (Kaharuddin, 2018), berdasarkan penelitiannya dapat dilihat bahwa hasil belajar siswa yang diajarkan dengan model pembelajaran kooperatif tipe Make a Match lebih tinggi dari pada hasil belajar siswa yang diajarkan dengan model pembelajaran langsung, karena pada model pembelajaran kooperatif tipe Make a Match memberikan kesempatan kepada siswa untuk saling memberikan pendapat atau ide yang mereka miliki.

Berdasarkan pembahasan hasil penelitian dapat disimpulkan bahwa terdapat peningkatan dari siklus I pertemuan 1 ke siklus II sebesar $61 \%$ dengan kategori sangat baik. Pada siklus II terdapat $89 \%$ persentase tingkat keberhasilan pembelajaran peserta didik sudah berada pada kriteria sangat baik. Sedangkan rata-rata nilai pada siklus II sebesar 82, penelitian ini sudah memenuhi kriteria keberhasilan sehingga penelitian ini dihentikan dan dinyatakan berhasil pada siklus II.

Berdasarkan pembahasan hasil penelitian yang telah di jelaskan tersebut, maka peneliti dapat menyimpulkan bahwa penelitian tindakan kelas pada tingkat keberhasilan penerapan model Make A Match terhadap hasil belajar kognitif pada pembelajaran IPA di kelas VI Sekolah Dasar Negeri 13 Pesing telah berhasil dilakukan.

\section{SIMPULAN}

Berdasarkan hasil penelitian dan pembahasan, dengan penerapan model Make A Match dapat meningkatkan hasil belajar kognitif pada pembelajaran IPA di Kelas VI Sekolah Dasar Negeri 13 Pesing. Adapun peningkatan tersebut pada hasil kognitif post tes ditunjukan dengan hasil belajar pada siklus II dengan persentase nilai post tes $89 \%$ meningkat dengan peningkatan persentase nilai post tes meningkat sebesar $61 \%$ dari siklus I dengan persentase hasil belajar peserta didik nilai post tesnya 28\%. Dari uraian hasil belajar kognitif tersebut, peneliti menyimpulkan bahwa pembelajaran dengan penerapan model Make A Match dapat meningkatkan hasil belajar kognitif peserta didik sehingga tujuan dari penelitian ini tercapai dengan hasil yang memuaskan. 
ADI WIDYA: Jurnal Pendidikan Dasar

FAKULTAS DHARMA ACARYA

UNIVERSITAS HINDU DARMA NEGERI

DENPASAR
Volume. 6, Nomor 2 Bulan Oktober 2021

ISSN: 2685-8312 (online)

ISSN: 2527-5445 (cetak)

http://ejournal.ihdn.ac.id/index.php/AW

Simpulan berisikan substansi pemaknaan tentang tujuan yang dielaborasikan dengan hasil dan pembahasan, sehingga ada keterkaitan/simpulan. Bagian ini juga dapat ditambah tentang tindak lanjut hasil penelitian ke depannya.

\section{DAFTAR PUSTAKA}

Aziz, A. (2015). Peningkatan Mutu Pendidikan. Jurnal Studi Islam Peningkatan Mutu, 10(2), 1-14.

Bahri, S., \& Mustajab, A. (2020). Pengaruh Model Pembelajaran Kooperatif Jigsaw Terhadap Aktivitas Belajar Siswa Pada Pelajaran IPA. Jurnal Sikola: Jurnal Kajian Pendidikan Dan Pembelajaran, 2(2), 126-134. https://doi.org/10.24036/sikola.v2i2.97

Basuki, W. (2003). Penelitian Tindakan Kelas. Dirjen Dikdasmen.

Fiteriani, I., \& Baharudin. (2017). Analisis Perbedaan Hasil Belajar Kognitif Menggunakan Metode Pembelajaran Kooperatif yang Berkombinasi Pada Materi IPA di MIN Bandar Lampung. Jurnal Pendidikan Dan Pembelajaran Dasar, 2(2), 1-30.

Juliani, A., Mustadi, A., \& Lisnawati, I. (2021). "Make A Match Model" for Improving the Understanding of Concepts and Student Learning Results. Indonesian Journal on Learning and Advanced Education (IJOLAE), 3(1), 48-56. https://doi.org/10.23917/ijolae.v3i1.10269

Kaharuddin, A. (2018). Keefektifan Model Make A Match dalam Pembelajaran Matematika Siswa Kelas VI Sekolah Dasar di Kecamatan Marioriwawo. Madrasah, 11(1). https://doi.org/18860/madrasah.v11i1.5563

Kurniawan, A., Rustaman, N. Y., Kaniawati, I., \& Hasanah, L. (2017). Profile of Cognitive Ability and Multiple Intelligence of Vocational Students in Application of Electric Energy Conservation. Journal of Physics: Conference Series, 895(1). https://doi.org/10.1088/1742-6596/895/1/012165

Melda, E., Kashardi, K., \& Hidayat, T. (2019). Kemampuan Kognitif Belajar Siswa dengan menggunakan Model Pembelajaran Inkuiri danProject Based Learning SMPN 5 Seluma. Seminar Nasional Sains ..., 1-10.

Mikran, M., Pasaribu, M., \& Darmadi, I. W. (2014). Penerapan Model Pembelajaran Kooperatif Make A Match untuk Meningkatkan Hasil Belajar Siswa Kelas VIIA SMP Negeri 1 Tomini pada Konsep Gerak. JPFT (Jurnal Pendidikan Fisika Tadulako Online), 2(2), 9. https://doi.org/10.22487/j25805924.2014.v2.i2.2781

Mustajab, A., Bahri, S., \& Julyanto, Y. (2020). 7-Step PBL: Problem Solving Ability of Students in Work $\begin{array}{llllll}\text { and Energy. JIPF (Jurnal Ilmu Pendidikan Fisika), } & \text { 5(3), }\end{array}$ https://doi.org/10.26737/jipf.v5i3.1838

Prihatiningsih, E., \& Setyanigtyas, E. W. (2018). Pengaruh Penerapan Model Pembelajaran Picture and Picture Dan Model Make a Match Terhadap Hasil Belajar Siswa. Jurnal Pendidikan Sekolah Dasar, 4(1), 1. https://doi.org/10.30870/jpsd.v4i1.1441

Rijal, S., \& Bachtiar, S. (2015). Hubungan antara Sikap, Kemandirian Belajar, dan Gaya Belajar dengan Hasil Belajar Kognitif Siswa. Jurnal Bioedukatika, 3(2), 15. https://doi.org/10.26555/bioedukatika.v3i2.4149

Sirait, Makmur, and P. A. N. (2013). Pengaruh Model Pembelajaran Kooperatif Tipe Make A Match Terhadap Hasil Belajar Siswa. Jurnal INPAFI, 1(8).

Subekti, Y., \& Ariswan, A. (2016). Pembelajaran fisika dengan metode eksperimen untuk meningkatkan hasil belajar kognitif dan keterampilan proses sains. Jurnal Inovasi Pendidikan IPA, 2(2), 252. https://doi.org/10.21831/jipi.v2i2.6278

Susanti, V. D. (2018). Analisis Kemampuan Kognitif dalam Pemecahan Masalah Berdasarkan Kecerdasan Logis-Matematis. Jurnal Matematika Dan Pendidikan Matematika, 3(1), 71-83.

Syamsijulianto, T. (2020a). Media Pembelajaran Mobuya Untuk Pembelajaran Keragaman Budaya. Jurnal Penelitian Dan Pengembangan Pendidikan, 4(1), 10. https://doi.org/10.23887/jppp.v4i1.23971 
ADI WIDYA: Jurnal Pendidikan Dasar

FAKULTAS DHARMA ACARYA

UNIVERSITAS HINDU DARMA NEGERI

DENPASAR
Volume. 6, Nomor 2 Bulan Oktober 2021

ISSN: 2685-8312 (online)

ISSN: 2527-5445 (cetak)

http://ejournal.ihdn.ac.id/index.php/AW

Syamsijulianto, T. (2020b). Penerapan Media Pembelajaran Mobuya pada Indahnya Keragaman Budaya Bangsaku di Sekolah Dasar. Briliant: Jurnal Riset Dan Konseptual, 5(2), 209. https://doi.org/10.28926/briliant.v5i2.449

Syamsijulianto, T., Hidayat, A., \& Zainudin, M. (2020). Pengenalan Indahnya Keragaman Budaya Negeriku Melalui Media Pembelajaran Mobuya. Jurnal Pendidikan: Teori, Penelitia, \& Pengembangan, 5(10), 8 .

Tarigan, D. (2014). Meningkatkan Aktivitas Belajar Siswa dengan Menggunakan Model Make A Match Pada Mata Pelajaran Matematika di Kelas V SDN 050687 Sawit Seberang. Kreano: Jurnal Matematika Kreatif-Inovatif, 5(1), 56-62. https://doi.org/10.15294/kreano.v5i1.3278

Wibowo, K. P., \& Marzuki, M. (2015). Penerapan Model Make a Match Berbantuan Media Untuk Meningkatan Motivasi Dan Hasil Belajar Ips. Harmoni Sosial: Jurnal Pendidikan IPS, 2(2), 158169. https://doi.org/10.21831/hsjpi.v2i2.7667

Wiyoko, T., \& Aprizan, A. (2020). Analisis Profil Kemampuan Kognitif Mahasiswa PGSD Pada Mata Kuliah Ilmu Alamiah Dasar. IJIS Edu: Indonesian Journal of Integrated Science Education, 2(1), 28. https://doi.org/10.29300/ijisedu.v2i1.2384

Yanti, M. T., Kuntarto, E., \& Kurniawan, A. R. (2020). Pemanfaatan Portal Rumah Belajar Kemendikbud Sebagai Model Pembelajaran Daring Di Sekolah Dasar. Adi Widya Jurnal Pendidikan Dasar, 10(1), 61-68. 